\title{
PENAMBAHAN GLUKOSA PADA MEDIA BEKATUL AGAR UNTUK PERTUMBUHAN Aspergillus sp
}

\author{
Mujahidah Basarang1), Muh. Rifo Rianto ${ }^{1)}$, Magfirah Arifuddin ${ }^{1)}$ \\ ${ }^{1)}$ Akademi Analis Kesehatan Muhammadiyah Makassar \\ Alamat Korespondensi: peatoduri@yahoo.com
}

\begin{abstract}
Abstrak
Pembiakan jamur di laboratorium dipengaruhi oleh komponen nutrien media. Media harus mengandung semua nutrisi yang mudah digunakan mikroba. Persyaratan media petumbuhan jamur adalah tersedianya karbohidrat dan nitrogen. Bekatul mengandung karbohidrat sebanyak $84,36 \%$ yang merupakan salah satu sumber energi utama dalam pertumbuhan dan perkembangan jamur. Selain itu bekatul merupakan sumber nitrogen yang kompleks. Oleh karena itu bekatul dapat dijadikan sebagai media alternatif pertumbuhan jamur. Tujuan penelitian ini adalah untuk mengetahui pertumbuhan jamur Aspergillus sp pada media bekatul agar. Selain itu penelitian ini bertujuan membandingkan pertumbuhan Aspergillus sp pada bekatul agar dengan penambahan glukosa dan bekatul agar tanpa penambahan glukosa. Metode yang digunakan adalah single dot dengan cara inokulasi Aspergillus sp menggunakan ose jarum yang ditusukkan di bagian tengah permukaan agar dan diinkubasi pada suhu $25{ }^{\circ} \mathrm{C}$. Pertumbuhan jamur dilihat dari hasil pengukuran diameter koloni jamur dilakukan setiap 24 jam selama 5 hari. Hasil pengamatan memperlihatkan gambaran pertumbuhan optimum Aspergillus sp. pada media bekatul agar, media bekatul agar penambahan glukosa. Pertumbuhan eksponensial Aspergillus sp. dimulai pada jam ke-24, jamke-48 dan jam ke-72. Kemudian dari jam ke-72 sampai jam ke-102 Aspergillus sp. mengalami fase pertumbuhan stasioneri. Dari penelitian ini dapat disimpulkan bahwa bekatul dapat dimanfaatkan sebagai media pertumbuhan jamur Aspergillus sp.
\end{abstract}

Kata kunci : Media Bekatul Agar, Pertumbuhan Aspergillus sp.

\section{PENDAHULUAN}

Media menjadi sesuatu yang penting dalam pertumbuhan jamur karena akan mempengaruhi morfologi, warna koloni dan jumlah koloni. Secara kimiawi media pertumbuhan dibedakan menjadi dua, yaitu media sintetik dan media nonsintetik. Media sintetik memiliki kandungan yang diketahui secara terperinci, yaitu senyawa organik dan inorganik ditambahkan harus murni. Media sintetik yang secara selektif menumbuhkan jamur adalah Sabouraud Dextrose Agar (SDA) atau Potato dextrose Agar (PDA) karena keasamannya rendah ( $\mathrm{pH}$ 4,5-5,6) sehingga menghambat pertumbuhan bakteri (Cappucino, 2014). Penelitian Mikrobiologi seringkali terkendala pada media yang harganya mahal dan susah didapatkan khususnya pada negara berkembang. Oleh karena itu dibutuhkan media dengan formulasi baru yang mudah didapatkan dan harga lebih murah dibandingkan media sintetik seperti SDA atau PDA.
Media nonsintetik menggunakan bahan-bahan yang terdapat di alam yang seringkali tidak diketahui kandungan kimianya secara rinci tapi sering digunakan di laboratorium karena mudah disiapkan dan harganya murah. Beberapa penelitian yang menggunakan bahan alam sebagai media elternatif seperti pati singkong (Kwoseh et al, 2012), kacang tunggak, kacang hijau, kacang soya hitam, dan kedelei (Ravimannan et al, 2014), ganyong, gembili dan garut (Aini dan Rahayu, 2015), dan sereal, kacangkacangan (Uthayasooriyan, et.al., 2016).

Melimpahnya sumber daya alam Indonesia memungkinkan ditemukan media alternatif pengganti SDA (Sabouraud Dextrose Agar). Salah satu bahan alam yang berpotensi sebagai media pertumbuhan adalah bekatul.

Bekatul adalah bahan alam yang merupakan limbah halus yang diperoleh dari proses penggilingan gabah padi. Produksi bekatul dari penggilingan padi di Indonesia mencapai 4-6 juta ton per tahun. Menurut catatan Pusat Penelitian 
dan Pengembangan Pertanian Bogor, kegiatan penyosohan beras bisa mengikis $7,5 \%$ dari bobot beras awal. Tujuh setengah persen tersebut berupa bekatul yang memiliki kadar selulosa dan hemiselulosa yang paling tinggi dibandingkan dengan berasnya itu sendiri (Nursalim dan Razali, 2007). Bekatul mempunyai sumber karbon dan nitrogen lebih kompleks dibanding media lain (Satyawiharja 1984 dalam Dewi et al, 2005). Pemanfaatan bekatul sebagai media pertumbuhan mikroorganisme didasarkan pada kandungan komponenkomponen nutrisi yang dibutuhkan mikroorganisme. Bekatul mengandung karbohidrat tinggi, protein, lemak, vitamin, dan serat kasar (Houston 1972 dalam Dewi et al, 2005).

Bekatul mempunyai kandungan vitamin B. Vitamin B tertentu yang terdapat dalam medium merupakan faktor penting untuk pertumbuhan jamur. Beberapa penelitian menunjukkan bahwa bekatul dapat dimanfaatkan sebagai media untuk pertumbuhan jamur penghasil enzim, seperti Aspergillus niger, Rhizopus sp, dan Mucor sp. Dengan kata lain, bekatul dapat digunakan sebagai substrat untuk menghasilkan enzim. Jenis enzim yang dihasilkan tergantung pada media dan kondisi lingkungan (Houston 1972 dalam Dewi et al, 2005).

Untuk mempelajari karakteristik mikroorganisme seperti jamur tergantung pada kultur di laboratorium. Komponenkomponen yang terdiri atas nutrisi penting pada bekatul menjadi syarat pertumbuhan optimal jamur, seperti Aspergillus $s p$ pada media bekatul seperti pada media sintetik seperti SDA yang telah banyak digunakan. Media padat, yaitu media agar lebih mudah digunakan untuk keperluan identifikasi dari spesimen patologi dan dapat mengurangi kontaminasi dibandingkan media cair. Media cair sangat susah disiapkan untuk mengkultur, identifikasi mikroorganisme dan kemungkinan terjadi kontaminasi sangat tinggi (Prescot, et.al.(2002) dalam Kowesh, et.al. (2012)).

SDA didukung oleh sumber karbon berupa penambahan gula sederhana berupa dextrosa. Molekul sederhana seperti glukosa akan langsung diserap oleh hifa jamur sebagai saprofit. Oleh karena itu dibutuhkan modifikasi media dengan penambahan glukosa pada bekatul agar untuk mengoptimalkan pertumbuhan jamur. Pengayaan media tersebut akan memberikan peluang bagi jamur yang kurang tumbuh subur pada media SDA akan tumbuh lebih baik. Penambahan glukosa dalam medium SDB (Sabouraud Dextrose Broth) dapat mempengaruhi pertumbuhan $C$. albicans. Pada $C$. albicans isolat klinik penambahan glukosa 5\% dan $10 \%$ selama 7 hari menyebabkan peningkatan pertumbuhan yang signifikan (Leepel et al, 2009). Sehingga penambahan glukosa sebagai sumber karbon pada media bekatul agar dapat memacu pertumbuhan Aspergillus $s p$ lebih cepat dan optimal.

Berdasarkan uraian di atas peneliti tertarik untuk mengetahui pertumbuhan Aspergillus sp pada media bekatul agar baik pada bekatul agar yang ditambahkan glukosa maupun tidak.

\section{METODE PENELITIAN}

\section{Alat dan Bahan}

Alat yang digunakan dalam penelitian ini adalah autoklaf, incubator, hotplate, timbangan digital, erlenmeyer, gelas ukur, beker gelas, batang pengaduk, sendok tanduk, nall/ose, corong, cawan petri, wadah sampel, kertas saring, ayakan, dan alat tulis.

Bahan yang digunakan adalah sampel bekatul, kultur jamur Aspergillus $s p$, agar, gula, kloramfenikol, dan aquadest.

\section{Prosedur Kerja}

\section{Persiapan sampel}

Sampel bekatul terlebih dahulu dipisahkan dari kandungan beras-beras halus dan kotoran dengan menggunakan ayakan,

\section{Pembuatan media bekatul agar}

Media bekatul dibuat berdasarkan prosedur dari Aini dan Rahayu (2015) yang telah dimodifikasi. Timbang sampel bekatul dan agar dengan menggunakan timbangan digital dan dimasukkan ke dalam gelas beker $1000 \mathrm{ml}$. Ke dalam 
gelas beker ditambahkan $1000 \mathrm{ml}$ aquades. Media dipanaskan dengan menggunakan hot plate sambil diaduk sampai larut dengan sempurna. Bekatul agar suhu $\pm 50{ }^{\circ} \mathrm{C}$ yang telah disterilkan dituang ke cawan petri 15-20 ml. Diamkan

\section{Pembuatan media bekatul agar + glukosa}

Bekatul, gula dan agar ditimbang dengan menggunakan timbangan digital dan dimasukkan ke dalam gelas beker $1000 \mathrm{ml}$. Ke dalam gelas beker ditambahkan $1000 \mathrm{ml}$ aquades. Media dipanaskan dengan menggunakan hot plate sambil diaduk sampai larut dengan sempurna. Bekatul agar suhu $\pm 50{ }^{\circ} \mathrm{C}$ yang telah disterilkan dituang ke cawan petri $15-20 \mathrm{ml}$. Diamkan media sampai memadat.

\section{Pembuatan media SDA}

Media SDA dimasukkan ke dalam erlenmeyer, lalu ditambahkan aquades steril. Media dihomogenkan dengan bantuan pemanasan dan pengadukan. Setelah proses sterilisasi, media suhu \pm $50{ }^{\circ} \mathrm{C}$ dituangkan ke cawan petri. Media didiamkan sampai memadat.

\section{Inokulasi jamur Aspergillus sp}

Metode penanaman jamur pada media yang digunakan adalah single dot. Aspergillus sp. diinokulasikan pada media bekatul agar dan media SDA menggunakan ose jarum dan ditusukkan dibagian tengah permukaan agar. Pengamatan pertumbuhan jamur dilakukan dengan mengamati pada hari/jam keberapa jamur tersebut tumbuh dan mengukur diameter koloninyanya. Perlakuan terhadap media bekatul dilakukan dengan tiga kali ulangan dengan media SDA sebagai kontrol.

Pengamatan mikroskopik jamur Aspergillus sp

Untuk memastikan Aspergillus sp yang tumbuh maka perlu dilakukan uji konfirmasi dengan pengamatan mikroskoppada perbesaran 10x40 untuk melihat hifa maupun spora dari jamur Aspergillus sp.

\section{Analisis data}

Adapun tekhnik analisa data pada penelitian ini menggunakan analisis deskriptif yaitu mendeskripsikan pertumbuhan koloni Aspergillus sp. dari pengukuran diameter koloni. Diameter koloni Aspergillus sp. pada media bekatul agar, media bekatul agar penambahan glukosa dan media SDA dibandingkan dalam bentuk tabel dan grafik.

\section{HASIL DAN PEMBAHASAN}

Untuk tumbuh dan berkembang, jamur membutuhkan nutrien dan faktorfaktor lingkungan yang sesuai. Nutrien berupa unsur-unsur atau senyawa kimia dari lingkungan digunakan sel sebagai konstituen kimia penyusun sel. Menurut Basu, et.al. (2015), jamur akan tumbuh optimal pada media dengan sumber karbohidrat dan nitrogen yang tinggi. Media bekatul agar menggunakan bekatul sebagai sumber nutrisi bagi jamur karena mengandung karbohidrat $(84,36 \%)$ dan protein $(8,77 \%)$. Tercukupinya sumber karbon dan protein bagi Aspergillus $s p$. dalam media bekatul agar memicu pertumbuhan Aspergillus sp tersebut.

Pertumbuhan Aspergillus sp pada bekatul agar dinyatakan dalam bentuk diameter koloni Aspergillus sp. yang diukur setiap 24 jam selama 5 hari. Hasil pengukuran disajikan dalam tabel 1 berikut.

Tabel 1. Diameter koloni Aspergillus sp pada media bekatul dan media SDA.

\begin{tabular}{cccc}
\hline \multirow{2}{*}{$\begin{array}{c}\text { Inkubasi } \\
\text { Selama } \\
\text { (Jam) }\end{array}$} & \multicolumn{3}{c}{$\begin{array}{c}\text { Rata-rata Diameter Koloni } \\
\text { pada Media (Dalam mm) }\end{array}$} \\
\cline { 2 - 4 } & $\begin{array}{c}\text { Bekatul } \\
\text { Agar }\end{array}$ & $\begin{array}{c}\text { Bekatul } \\
\text { Agar }+ \\
\text { Glukosa }\end{array}$ & SDA \\
\hline 24 & 10.33 & 10.5 & 11 \\
48 & 33.5 & 33.7 & 35 \\
72 & 60.5 & 61 & 57 \\
96 & 77.5 & 77.8 & 69 \\
120 & 90 & 90 & 80 \\
\hline
\end{tabular}

Berikut adalah grafik pertumbuhan jamur Aspergillus $s p$ pada media bekatul dan 


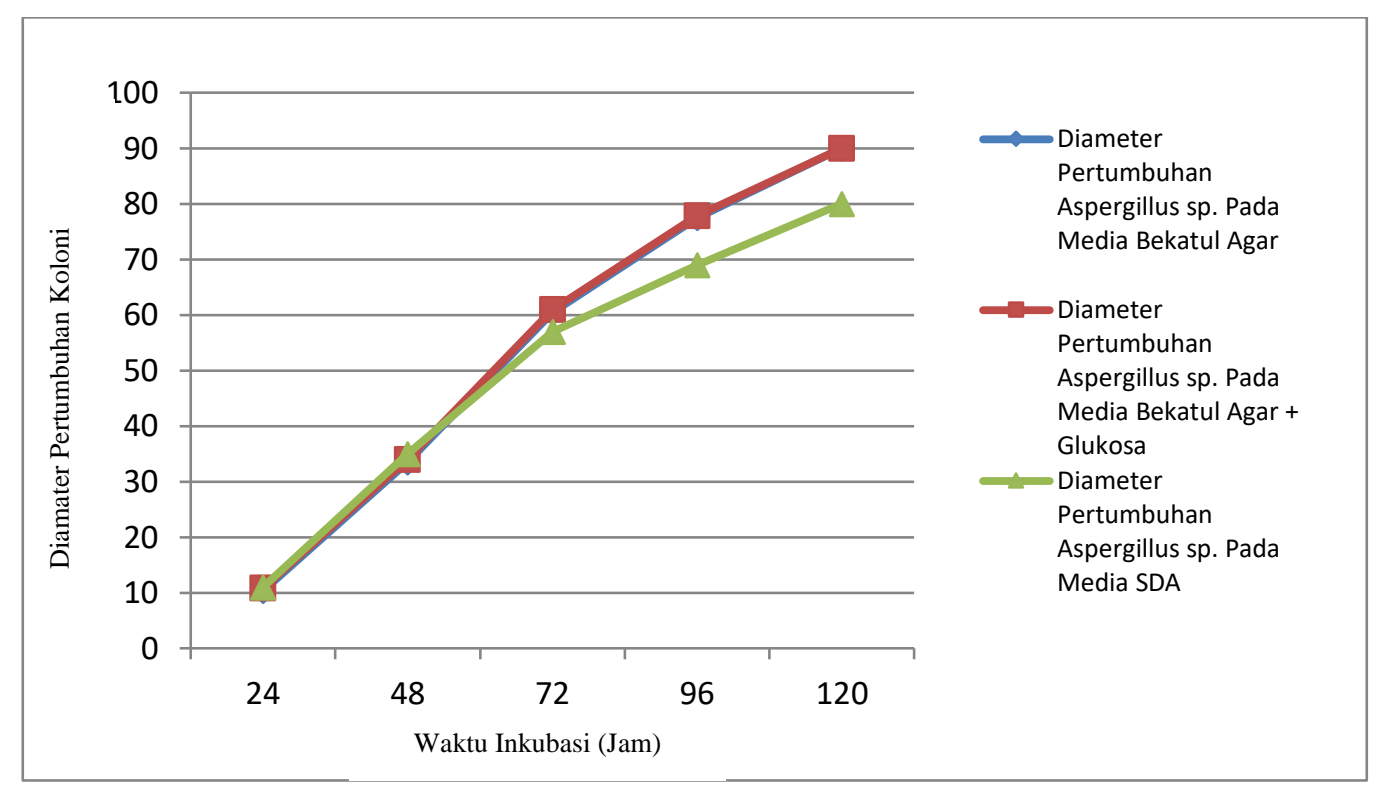

Gambar 1. Grafik pertumbuhan jamur Aspergillus sp pada media bekatul agar dan SDA

Dari grafik di atas terlihat pertumbuhan jamur Aspergillus sp yang diinokulasi pada media bekatul agar dan diinkubasi pada suhu kamar $\left(25{ }^{0} \mathrm{C}\right)$ dalam waktu 24 jam memperlihatkan adanya pertumbuhan ditandai dengan terbentuknya koloni jamur.

Diagram di atas menunjukkan fase pertumbuhan Aspergillus sp. pada tiga media berbeda. Jam ke-0 sejak inokulasi dilakukan sampai terbentuk benangbenang halus pada permukaan media pada jam ke-24 ditemukan rata-rata diameter koloni 10,33 $\mathrm{mm}$ pada media bekatul, $10,5 \mathrm{~mm}$ pada media bekatul agar dengan penambahan glukosa dan pada media SDA $11 \mathrm{~mm}$. Hal ini menandakan terjadi pertumbuhan Aspergillus sp.

Menurt Gandjar (20016), salah satu parameter pertumbuhan adalah pertambahan volume sel, karena adanya pertambahan protoplasma dan senyawa asam nukleat. Pertambahan volume sel tersebut adalah irreversibel, artinya tidak dapat kembali ke volume semula. Pada umumnya suatu koloni digunakan sebagai kriteria terjadinya pertumbuhan, karena massa sel tersebut berasal dari satu sel. Jadi sesuatu yang semula tidak terlihat, yaitu suatu spora atau konidia jamur, menjadi miselium atau koloni yang dapat dilihat. Jika suatu konidia atau spora jamur ditanam di atas agar dalam cawan petri, maka setelah satu atau dua hari akan terlihat struktur berupa benang-benang pada permukaan agar, pemeriksaan mikroskopis membuktikan bahwa yang tumbuh adalah koloni Apergillus $s p$.

Pertumbuhan Aspergillus sp. pada jam ke-0 sampai jam ke-24 merupakan fase lag (fase awal) yaitu fase penyesuaian sel-sel jamur dengan lingkungannya. Pada fase ini tidak ada peningkatan jumlah sel, melainkan peningkatan ukuran dan besar sel.

Pertumbuhan jamur pada jam ke-48 menunjukkan pertumbuhan terbaik pada media SDA sebagai kontrol dengan diameter $35 \mathrm{~mm}$, sedangkan pada media bekatul agar dan media bekatul agar penambahan glukosa memiliki diameter yang hampir sama. Hal ini berbeda pada jam ke-72, Aspergillus sp. mengalami pertumbuhan terbaik pada media bekatul agar penambahan glukosa, yaitu $61 \mathrm{~mm}$. Pada jam ke-24 sampai jam ke-72 terlihat pertumbuhan Aspergillus sp. mengalami peningkatan secara eksponensial pada kurva pertumbuhan pada grafik. Pertumbuhan berlangsung cepat dan merupakan periode yang di dalamnya biasanya teramati ciri khas sel-sel yang 
aktif. Pada fase ini diameter pertumbuhan Aspergillus sp. pada media tidak

Pada jam ke-96 sampai jam ke-120 pertumbuhan Aspergillus sp. memasuki fase stationeri. Hal ini terlihat pada kurva pertumbuhan mengalami penurunan. Grafik tidak mengalami pertambahan secara eksponensial seperti pada pertumbuhan jam ke-24 sampai jam ke72. Fase ini ditandai dengan kecepatan tumbuh sama dengan kecepatan kematian sel, sehingga jumlah sel konstan (tetap). Hal ini disebabkan berkurangnya substrat, kepadatan populasi sel sangat tinggi, tekanan parsial oksigen yang rendah serta adanya akumulasi produk metabolisme yang toksik. Fase transisi antara fase stasioner dengan fase eksponensial merupakan periode pertumbuhan tak seimbang karena laju sintesis berbagai komponen seluler tidak sama. Akibatnya sel-sel pada fase ini memiliki komposisi kimiawi yang berbeda dengan fase eksponensial (Ali, 2005).

Komponen media merupakan kriteria penting untuk kultur dan studi jamur. Media menjadi parameter penting fisiologis jamur yang menyebabkan sporulasi maksimum (Gupta, et. al., 2012). Diameter koloni, karakteristik (tekstur, permukaan, dan pewarnaan, zonasi) dan sporulasi jamur uji sangat dipengaruhi oleh jenis medium pertumbuhan yang digunakan (Sharma, 2010). Pada permukaan koloni tampak seperti tepung atau granula menandakan spora diproduksi secara berlimpah. Pada jam ke-120, diameter koloni memenuhi memenuhi permukaan media, baik media bekatul agar ataupun media bekatul agar dengan penambahan glukosa. Berbeda dengan media SDA, diameter koloni masih dapat di ukur yaitu $80 \mathrm{~mm}$. Perbedaan pertumbuhan jamur Aspergillus sp pada media bekatul dan media SDA sangat nampak, permukaan koloni pada media SDA seperti benangbenang halus berwarna hitam namun spora yang dihasilkan belum nampak. Sedangkan gambaran koloni Aspergillus $s p$ pada media bekatul agar dan media bekatul agar dengan penambahan glukosa warna hitam pekat dan ada pula yang berwarna hijau tua. Spora yang dihasilkan pada media bekatul terlihat subur membentuk gundukan. Hal ini disebabkan karena media bekatul memiliki komposisi lengkap dengan kandungan gizi yang cukup tinggi.

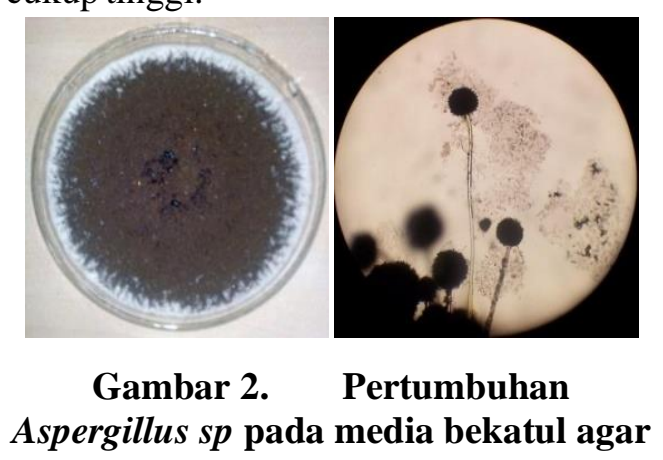

Pada media bekatul agar dan media bekatul agar penambahan glukosa koloni Aspergillus $s p$ memiliki gambaran koloni yang sama. Penambahan glukosa sederhana akan menopang pertumbuhan jamur. Hal ini disebabkan karena ukuran molekul glukosa dapat diserap secara langsung oleh hifa Aspergillus sp. akan tetapi perbedaan diameter ini menunjukkan perbedaan yang tidak terlalu besar.

Kandungan gizi bekatul tersusun dari beberapa zat, seperti air, protein, lemak, vitamin, mineral, serat dan karbohidrat. Berdasarkan analisis yang dilakukan oleh Sucofindo kandungankandungan tersebut dapat berupa air $2,49 \%$, protein $8,77 \%$, lemak $1,09 \%$, abu $1,60 \%$, serat $1,69 \%$, karbohidrat $84,36 \%$ dan kalori 382,32 kal (Nursalim dan Razali, 2007). Kandungan nutrisi pada media bekatul ini sangat kompleks dan kaya gizi sehingga dapat mempengaruhi pertumbuhan jamur Aspergillus $s p$ ini baik itu warna koloni, ukuran sel, maupun kecepatan pertumbuhan.

\section{KESIMPULAN}

Berdasarkan penelitian yang telah dilakukan dapat disimpulkan bahwa:

1. Aspergillus sp. mengalami pertumbuhan optimal pada media bekatul agar baik pada media yang ditambahkan glukosa maupun tanpa penambahan.

2. Bekatul dapat dimanfaatkan sebagai media pertumbuhan Aspergillus $s p$ 
SARAN

Saran dari penelitian ini yaitu lebih memperhatikan kualitas bekatul yang digunakan serta tempat penyimpanannya. Selain itu untuk peneliti selanjutnya, perlu dilakukan penelitian tentang ukuran bekatul sebagai media pertumbuhan jamur.

\section{DAFTAR PUSTAKA}

Aini, N., dan Rahayu, T. 2015. Media Alternatif untuk Pertumbuhan Jamur Menggunakan Sumber Karbohidrat yang Berbeda (Skripsi). Surakarta: Universitas Sebelas Maret.

Ali, A. 2005. Mikrobiologi Dasar Jilid I. Makassar: Badan Penerbit Universitas Negeri Makassar.

Basu, et.al. 2015. Evolution of Bacterial and Fungal Growth Media. Bioinformation 11(4): 182-184.

Brooks, G.F. et al. 2005. Mikrobiologi Kedokteran Jawets, Melnick \& Adelberg's Ed. 25. Alih Bahasa: Aryandhito Widhi Nugroho, dkk. Jakarta: Penerbit Buku Kedokteran EGC.

Dewi, C., Purwoko, T., dan Pangastuti, A. 2005. Produksi Gula Reduksi oleh Rhizopus oryzae dari Substrat Bekatul, (online). Bioteknologi 2 (1): 21-26.

Gandjar, I. et al. 2006. Mikologi Dasar dan Terapan. Jakarta: Yayasan obor Indonesia.

Goldman, G., H. dan Osmani., S., A. 2008. The Aspergilli. Genomics, Medical Aspects, Biotechnology, and Research Methods. United Stated of America: CRP Press Taylor and Francis Group.

Gupta, M., Manisha, K., dan Grover, R. 2012. Effect of various media types on the rate of growth of Aspergillus niger. Indian Journal of Fundamental and Applied Life Sciences Vol. 2 (2) April-June, pp.141-144.

Hidayat, N. et al. 2006. Mikrobiologi Industri. Yogyakarta: Andi Offset.

Kowesh, C.K., Darko, M.A., dan Adubofour, K. 2012. Cassava starch-agar blend as alternative gelling agent for mycological culture media. Bots. J. Agric. Appl. Sci. Vol. 8(1).

Leepel, L.A., et.al. 2009. Efek Penambahan Glukosa pada Saburoud Dextrose Broth Terhadap Pertumbuhan Candida albicans(Uji in Vitro). Indonesian Journal of Dentistry 2009; 16 (1):58- 63.

Nursalim, Y., dan Razali, Z.Y. 2007. Bekatul Makanan yang Menyehatkan.Agro Jakarta: Media Pustaka.

Ravimannan, N., et.al. 2104. Alternative culture media for fungal growth using different formulation of protein sources. Annals of Biological Research, 2014, 5 (1):36-39.

Sharma, D., dan Pandey, R. R. 2010. Influence of culture media on growth, colony character and sporulation of fungi isolated from decaying vegetable wastes. Journal of Yeast and Fungal Research Vol. 1(8), pp. $157-164$.

Uthayasooriyan, M., et.al. 2016. Formulation of Alternative Culture Media for Bacterial and Fungal Growth. Der Pharmacia Lettre 8 (1):431-436. 